\title{
Comparative assessment of TPHs and bioaccumulation in some fresh fish species in the Qua lbeo River of Eket of Akwa Ibom State in Nigeria
}

\author{
V. E. Okpashi ${ }^{1 *}$, V. N. Ogugua ${ }^{2}$, INE Onwurah, ${ }^{3}$ C. S. Ubani ${ }^{4}$ and T. C. Ezike, ${ }^{4}$ \\ ${ }^{1}$ Environmental Toxicology and Molecular Biochemistry Unit, University of Nigeria, Nsukka, Nigeria \\ ${ }^{2}$ Department of Medical Biochemistry, University of Nigeria, Nsukka, Nigeria \\ ${ }^{3}$ Department of Environmental Biotechnology and Biochemistry, University of Nigeria, Nsukka, Nigeria \\ ${ }^{4}$ Department of Industrial Biochemistry and Environmental Biotechnology, University of Nigeria, Nsukka, Nigeria
}

\begin{abstract}
This investigation was carried out in four different locations mapped out along the river bank. Twelve water samples were collected and six different fresh fish species that are frequently consumed were caught. They include: African red snapper (Lutjanus agennes), Yellow tail (Seriola lalandi), Barracuda (Sphyraena barracuda), Atlantic Croker (Micropogonias undulates), Catfish (Clarias gariepinus) and Tilapia (Oreochromis niloticus). Samples were subjected to screening using gas chromatography and flame ionization detector instrument. Results revealed presence of total petroleum hydrocarbon $(\mathrm{TPH})$ contaminant in all the fish samples and varies with species significantly at $\mathrm{p} \geq 0.05$. The profound TPH compound is Nonane with molecular formula $\mathrm{C}_{9} \mathrm{H}_{20} .9 \times 10^{-9} \mathrm{mg} / \mathrm{l}$ was adapted as Nonane concentration in water samples. Nonane concentration in fish samples showed African red snapper 3.9565 $\pm 4.64648 \mathrm{mg} / \mathrm{l}$, Yellow tail $8.7243 \pm 2.15546 \mathrm{mg} / \mathrm{l}$, Barracuda $6.2555 \pm 0.48889 \mathrm{mg} / \mathrm{l}$, Atlantic Croker $9.3866 \pm 0.42208 \mathrm{mg} / \mathrm{l}$, Catfish $4.1973 \pm 1.52959 \mathrm{mg} / \mathrm{l}$ and Tilapia $6.0039 \pm 0.96487 \mathrm{mg} / \mathrm{l} \mathrm{respectively}$. The bioaccumulation factor varies in fish species, where the Yellow tail have higher bioaccumulation factor 969,369061, followed by Barracuda 695,067209, Tilapia 667,101072, Catfish 466,368366, African red Sniper 439,616275 and Crocker fish 104,2956024 respectively. This investigation reveal considerably the extent of bioaccumulation of TPH contaminants in aquatic animal models and making unsafe for consumption as some fishes bio-accumulate nonane beyond permissible limit.
\end{abstract}

Keywords: Bioaccumulation; TPH; Nonane contaminants; Fish species and human health risk

\section{Introduction}

The need to find and establish evidence associated with patient specific health effect and environmental interaction in disease, mediated by exposure to environmental contaminants in diverse animal models, for assessment of human health risk, is the rationale of this investigation. The number of identified individual hydrocarbon components of various petroleum products has been estimated at over a thousand. Toxicity data are available for about 95, but only about 25 were considered to have sufficient data to develop toxicity criteria according to the Total Petroleum Hydrocarbon Criteria Working Group (TPHCWG 1997b). The TPHCWG (1997c) and the Massachusetts Department of Environmental Protection (MADEP) (Yasser and Naser, 2011) derived health guidance criteria for some of these compounds (TPH). Whole petroleum products are generally complex mixtures of hydrocarbons of varying carbon number and additives (usually representing a smaller weight percentage of the whole mixture) of varying chemical identities that are added to impart special qualities or enhance particular functional properties of the whole petroleum product. Additional impurities may be generated during use of the product (Yasser and Naser, 2011). Non-hydrocarbon additives and impurities are not included in the definition of TPH. Toxicological information on important petroleum products that are the subjects of other ATSDR toxicological profiles, and on other petroleum products that are the subject of assessment by other agencies, is briefly reviewed. Such information may be useful in characterizing acute exposure to fresh spills of petroleum products, but its usefulness is limited because of the limited availability of MRLs, the vari-

\footnotetext{
*Corresponding author. e-mail: victor.okpashi.pg64928@unn.edu.ng
} 
ability in the composition of petroleum products, and the change in composition due to environmental fate and transport processes (Beeby, 1993). Some pollutants in sufficient concentrations are toxic to marine organisms. These include both naturally occurring chemicals present in higher concentrations as a result of human activities as well as compounds that did not exist in nature until manufactured by humans (Pelletier, et al., 1997; Barron, et al., 2003). Other pollutants are harmful because they stimulate biological activity or alter habitats. Pollution emanates from either direct discharges or diffuse sources (Weber, 2003). Total Petroleum Hydrocarbon (TPH) is defined as the measurable amount of petroleum-based hydrocarbon in an environmental media. It is, thus, dependent on analysis of the medium in which it is found. Since it is a measured, gross quantity without identification of its constituents, the TPH "value" still represents a mixture. Thus, TPH itself is not a direct indicator of risk to humans or to the environment (Falk et al., 2004). Petroleum products are the source of the many components, but do not define what TPH is. They help define the potential hydrocarbons that become environmental contaminants. The problem of oil pollution in various marine and estuarine environments has received considerable scientific attention with respect to the effects of petroleum spills, as well as inherent toxicities to biological, ecosystem components and individual species (Calfee, et al., 1999). Petroleum products are carcinogens and affect a variety of biological processes and potent cell mutagens. Estimates revealed that about $6.1 \mathrm{mil}-$ lion metric tons of petroleum products were being released to global oceans annually (Capone and Bauer, 1992; Domask, 1998). Oil spills in the marine environment may affect organisms found there-in by direct toxicity or by physical smothering (Perry, 1990). Generally, crude oil is toxic to aquatic organisms e.g. Fish, due to the presence of TPH (Heintz et al., 1999). The presence of petroleum hydrocarbon in the marine environment is mediated by food chain in several ways. It has been reported that petroleum concentration, as low as $0.1 \mathrm{ppm}$ can be toxic to larvae of some species in the sea can affect marine life by interfering with the ability to breed, reproduce, grow, or perform other vital functions (USEPA, 1986; Mazhar et al., 1997; Anderson et al., 1994). Crude oil as a result of its TPH content; disrupt the development, immunity, reproduction, growth and survival of aquatic organisms (Brown, et al., 1996; Hall et al., 2006).
Tiido et al., 2006 attempt to show the carcinogenic pathway of a crude mixture of TPHs as less than the sum total of anticipated carcinogenicity when the potency of the known TPHs (carcinogen) in the crude mixture is considered.

\section{The Study Area}

The research location is Eket local government area of Akwa Ibom State, Nigeria. Eket Local Government area (LGA) occupies the South central portion of Akwa Ibom State. It lies entirely in the tropics with territorial expense, spanning Northwards between Latitude $4^{\circ} 33^{\prime \prime}$ and $4^{\circ} 45^{\prime \prime}$ and Eastward between Longitude $7^{\circ} 52^{\prime \prime}$ and $5^{\circ} 02^{\prime \prime}$. Eket is bounded on the north by Nsit Ubium LGA, on the east by Esit Eket LGA, on the west by Onna LGA and on the south by Ibeno LGA/Bright of Bonny.

Eket has a population of 172,557 , where the numbers of males are 88,563 and females, 83,994 (NPC, 2006). Recently, in April 2014, the government of Akwa Ibom State directed the ministry of economic development Uyo, to release a projected population growth beginning from 2007 to 2015 by adapting the 2006 population census figures. The document contained 2013 to 2015 population, approximated area $\left(\mathrm{km}^{2}\right)$ and population density of inhabitants per $\mathrm{km}^{2}$. Eket only, have a projected population of 218438 in 2013 and it was estimated that by 2015 , the population will increase to 233,544 , where the females will be 113,289 and males 120,255 dominant in $176000 \mathrm{~km}^{2}$.

The study was carried out in the lower Qua-Iboe river, a tributary of the Great Qua-Iboe River located in the Eastern part of Akwa-Ibom State, Nigeria. The Lower Qua-Iboe River flows from Ekpene-Ukpa in Etinan through Ibawa in OrukAnam Local Government Area. The river is $26 \mathrm{~km}$ from Uyo, the state capital. The river is located in the Central Akwa-Ibom with length of about $46 \mathrm{~km}$, bounded with NsitIbium Local Government Area (East), Mkpat-Enin Local Government Area (West), Onna Local Government Area (South), Uyo and Abak Local Government Area in the North. It is a tidal river. It flows North-South direction at low tide and South-North direction at high tide.

The need to qualitatively identify which compounds will 
bioaccumulate, to develop quantitative estimates of tissue concentrations of TPH contaminants, monitor existing bioaccumulation to predict bioaccumulation under future exposure conditions, and the use of aquatic animal model as a screening tool for accurate predictor compounds, gave impetus to this investigation. Symptoms of neurological dysfunction, such as ataxia, poor coordination and gait irregularities, are potential biomarkers of effect from acute or repeated high-level exposure to petroleum-derived hydrocarbons in the aliphatic EC5-EC8 and aromatic EC5-EC9 fractions (see ATSDR, 2007a-d). Such symptoms, shared by many hydrocarbons in these fractions, are not specific to petroleum hydrocarbons which indicates exposure to other substances such as halogenated hydrocarbons or neurotoxic metals. However, there are not expected from the low-level exposure to hydrocarbons in these fractions that is likely to be experienced by people or organisms residing in the vicinity of disposal sites contaminated with petroleum hydrocarbons.

\section{Materials and methods}

\section{Sampling locations}

Four sampling locations were marked out in order to achieve twelve sample points. The sampling locations were established based on ecological settings and human activities. The locations were approximately $1 \mathrm{~km}$ away from each other for collection of samples. A total of $3 \mathrm{~km}$ was covered from location 1 to location 4 .

\section{Location 1}

This sampling point was indicated as the upstream locations. It is located at Ikot Ikpe and Ikot Akpoenang at latitude $40^{\circ} 55.8^{\prime \prime}$ and longitude $7040.8^{\prime \prime}$. Activities in this area are mainly fishing and boat making at the River bank. The water is relatively clean at this location by human eye-sight evaluation.

\section{Location 2}

Location 2 receives effluents from the slaughter house located along the Ikot Aroku and Ikot Naidiba Village Road. Household from residential houses are also discharged into the River. The main activities are mining and loading of sand for commercial purposes. It is about $1 \mathrm{~km}$ away from station 1 and located at latitude 4022.9 " and longitude 70 13.8".

\section{Location 3}

This is located along Eket-Etinan Road, within Ebiyan and Ndon directly opposite Onna Local Government Area. Activities at this location include washing of cars, washing of motor bikes, washing of clothes and bathing. The vegetation is dominated with bamboo trees. It is about $1 \mathrm{~km}$ away from location 2 and located at latitude $4^{\circ} 23.2^{\prime \prime}$ and longitude $7^{\circ} 40.2^{\prime \prime}$.

\section{Location 4}

This is located at Ndilla, opposite villages across the river are Odio and Ale Ebukuku. This descended into Ibeno local government area, seeFigure 2 . The human activities include fishing and mining of sand. Vegetation is mainly mangrove. This area is turbid due to the discharge of much wastes, it is also very deep due to the mining activities. It is about $1 \mathrm{~km}$ away from location 3 and located at latitude $4^{\circ} 43.5^{\prime \prime}$ and longitude $70^{\circ} 53.3^{\prime \prime}$.

\section{Collection of river water sample}

River water samples were collected using 12 amber bottles, each $100 \mathrm{~mL}$ at twelve different points in Eket area of Akwa Ibom state on the 2nd May, 2015 between 10a.m to 3p.m along the coast. The samples collected were extracted with $\mathrm{n}$-hexane before concentrating the analytes or target compounds within 30 minutes.

\section{Reagents and chemicals}

All chemicals used were of analytical grade and were products of British Drug House (BDH) Chemical limited, Poole England.

\section{Collection of fish sample}

The biological sample (fish) were randomly collected to give a fair chance of probability since they are mobile organisms. Some variables that influenced site selection based on field 
work included proximity to oil well locations, gas flaring from Bonny Bright, high population density, socio-economic activities, particularly fishing within the area, with heavy presence of sewage, indiscriminate disposal of solid waste in and around the shore of Qua-Iboe river.

Locally consumed fresh African red snapper (Lutjanus agennes), Yellow tail (Seriola lalandi), Barracuda (Sphyraena barracuda), Atlantic Croker (Micropogonias undulates), Catfish (Clarias gariepinus) and Tilpia (Oreochromis niloticus) were collected for study by a resident fisherman using set nets. These species of fishes, irrespective of their sex and age were weighed. The fishes were wrapped in hexane-rinsed aluminum foil, labelled and placed inside closed-glass vessel containing ice pack and at below $-20^{\circ} \mathrm{C}$ before taken for laboratory analysis.

Preparation, extraction and clean-Up procedure of fish samples for analysis

Prior to extraction, the fish samples were scale-off using knife and subsequently dissected to obtain the tissues. $15 \mathrm{~g}$ of the fish tissue was placed in a clean mortar and ground with pestle with $40 \mathrm{~g}$ of anhydrous sodium sulphate until completely dried and homogenized. The sample extraction was carried out using dichloromethane (DCM). $10 \mathrm{~g}$ of the homogenized. sample was placed in $50 \mathrm{ml}$ extraction bottle and $1 \mathrm{~mL}$ of $60 \mathrm{ng} / \mathrm{ml}$ of 1- chloro-octadecane surrogate standard was added in the extraction bottle. The content was agitated or vortexed for $5 \mathrm{hrs}$ and allowed to settle for 1 hour. The sample was carefully filtered through a funnel fitted with cotton wool, silica gel and sodium sulphate $\mathrm{Na}_{2} \mathrm{SO}_{4}$ in a clean volumetric flask. The residue was washed and made up volume using the extracting solvent. The sample was concentrated to $2 \mathrm{ml}$ for TPHs analysis using a gas chromatography tandem flame ionization detector (GC-FID).

\section{Method of GC-FID}

The methodology that was used with GC-FID has the following conditions.

GCFID-QP2010 Plus, ion source temperature: $200.00{ }^{\circ} \mathrm{C}$, interface temperature: $250.00{ }^{\circ} \mathrm{C}$, solvent cut time: $2.50 \mathrm{~min}$ utes, detector gain mode: MS, detector gain: $0.00 \mathrm{kV}$, thresh- old: 2000 , column oven initial temperature: $70.0^{\circ} \mathrm{C}$, injection final temperature: $250.00{ }^{\circ} \mathrm{C}$, injection Mode: Split, flow control mode: linear velocity, pressure: $116.9 \mathrm{kPa}$, total Flow: $40.8 \mathrm{~mL} / \mathrm{min}$, column flow: $1.80 \mathrm{~mL} / \mathrm{min}$, linear velocity: $49.2 \mathrm{~cm} / \mathrm{sec}$, trap and purge flow: $3.0 \mathrm{~mL} / \mathrm{min}$,Split Ratio: 20.0, high pressure injection: OFF, Carrier Gas: Helium and Splitter hold: OFF. While oven rating was as follows:

Oven Temp. Program Rate Temperature $\left({ }^{\circ} \mathrm{C}\right) \quad$ Hold Time (min) $\begin{array}{lll}\text { Initial: } 0.00 & 70.0 & 0.00\end{array}$

$\begin{array}{lll}\text { Final: } 10.0 & 280 & 5.00\end{array}$

Extraction of fish and water samples for TPH determination

Liquid-liquid extraction procedure was used in this analysis. One litre of sample was extracted in a $2 \mathrm{~L}$ glass separator funnel fitted with a glass stopper using $30 \mathrm{~mL}$ hexane as extract. The separator funnel was vigorously shaken in 3 minutes and the organic layer was allowed to separate clearly from the aqueous phase for a minimum of 5 minutes, after which, the organic layer was collected into a separate glass bottle. The extraction was repeated thrice for each sample. Water residues was expelled from the organic layer by passing extracts through funnels containing anhydrous sodium sulphate. Extracts were concentrated using rotary evaporators with water bath preset at $85^{\circ} \mathrm{C}$. Concentrated extracts was transferred to a pre-weighed sample bottle and evaporated to dryness.

\section{Calculation of bioaccumulation factor}

The bioaccumulation factor was carried using the EPA (2000) method.

\section{Statistical analysis}

All investigations were carried out in triplicate and data obtained were presented as mean \pm standard deviation using descriptive statistics. One way analysis was used to compare mean variance among samples or groups. Significance was accepted at $\mathrm{p}<0.05$ level using SPSS version 18 software.

\section{Results and discussion}

This investigation covers total petroleum hydrocarbons (TPH), which is defined as the measurable amount of petro- 
leum-based hydrocarbon in an environmental medium. These products contain not only a large number and variety of petroleum hydrocarbons, but also other chemicals that are not the subject of this research, such as non-hydrocarbon additives and contaminants (EPA, 2000). The TPH issue is further complicated by the number of petroleum-derived hydrocarbons that have been identified-more than 250 and the variability in composition of crude oils and petroleum products (Kaladumo, 1996). The assessment of petroleum hydrocarbon-contaminated sites involved analysis. TPH is a loosely defined aggregate that depends on the method of analysis as well as the contaminating materials and represents the total mass of hydrocarbons without identification of individual components (Okpashi et al., 2015). TPH is not a consistent entity, the assessment of health effects and development of health guidance values, such as Minimal Risk Levels (MRLs) for TPH as a single entity are problematic (Moles and Norcoss, 1998). The results reveal the presence of Nonane as a constituent of total petroleum hydrocarbon in all the fish species as shown in table I. This was attributed to antropogenic activities, periodic crude oil spillage, and indiscriminate waste dumping among other contaminants. The concentration of nonane in biological samples (fishes) ranged from Croker (Micropogonias undulates) $9.3866 \pm 0.42208 \mathrm{mg} / \mathrm{L}$; Yellow tail (Seriola lalandi) $8.7243 \pm 2.15546 \mathrm{mg} / \mathrm{L}$; Barracuda (Sphyraena barracuda) $6.2555 \pm 0.48889 \mathrm{mg} / \mathrm{L}$; Tilapia (Oreochromis niloticus) $6.0039 \pm 0.96487 \mathrm{mg} / \mathrm{L}$; Catfish (Clarias gariepinus) $4.1973 \pm 1.52959$ and African Red snapper (Lutjanus agennes) $3.9565 \pm 4.64648 \mathrm{mg} / \mathrm{L}$ respectively. Hydrocarbons in the aliphatic EC>8-EC16 fraction may readily be absorbed in the lungs, widely distributed to tissues with preferential distribution and accumulation occurring in fatty tissues. The slow elimination from fatty tissue, as indicated by studies of humans exposed via inhalation to a mixture of
C10-C12 alkanes ("white spirit") and studies of rats exposed by inhalation to single alkanes or cycloalkanes in the C6C10 range Muniz et al. (2004).

Results of bioaccumulation factor in fish samples showed that Yellow tail (Seriola lalandi) have the highest bioaccumulation factor of 969,369061, followed by Barracuda (Sphyraena barracuda) 695, 067209; Tilapia (Oreochromis niloticus) 667, 101072; Catfish (Clarias gariepinus) 466, 368366; African Red snapper (Lutjanus agennes) 439,616275 and Croker (Micropogonias undulates) 104, 2956024 respectively. Other studies suggests that variability in concentration and accumulation of contaminants is due to age of the fish, location or exposure to contaminants, feeding habit of the fish, tissue size and lipid level among others. This research observed that the near or absolute absent of TPH in water media was due to machine calibration to five decimal places, which reduce the sensitivity and detection limit of the machine. An assumption of nine decimal places would give considerable or significant detection limit of some TPH components at trace concentration. For instance, the adoption of $9 \times 10^{-9} \mathrm{mg} / \mathrm{l}$ for water samples makes way for bioaccumulation factor computation. The calculation of bioaccumulation was done following API (2001).

For human volunteers exposed by inhalation to $100 \mathrm{ppm}$ white spirit for 3 hours, a mean pulmonary uptake of $392 \mathrm{mg}$ white spirit was measured, based on concentrations of white spirit in inspiratory and expiratory air (FAO, 2012). Hazard associated with nonane and other TPH derivative may cause lung damage if swallowed. Flammable vapors may cause dizziness or suffocation. Very toxic to aquatic organisms, may cause long-term adverse effects in the aquatic environment. Swallowing of the liquid may cause aspiration into the lungs with the risk of chemical pneumonitis; serious conse

\section{Table I. length and weight of fish samples}

\begin{tabular}{llcc}
\hline Common name of fish & Scientific name & Length $(\mathrm{cm})$ & Wet weight $(\mathrm{g})$ \\
\hline Atlantic Croker & Micropogonias undulates & 38 & 1184 \\
Catfish & Clarias gariepinus & 35 & 802 \\
Tilapia & Oreochromis niloticus & 24 & 456 \\
African red snapper & Lutjanus agennes & 28 & 543 \\
Yellow tail & Seriola lalandi & 37 & 902 \\
Barracuda & Sphyraena barracuda & 56 & 1234 \\
\hline
\end{tabular}


quences may result (Klerks et al., 2004). Most authorities agree that metabolic activation by the mixed-function oxidase system is a necessary prerequisite for TPH-induced carcinogenesis and mutagenesis (Neff, 1979). Fishes and most crustaceans tested to date possess the enzymes necessary for activation (IMO, 2005). Although many aquatic organisms possess the requisite enzyme, recent research carried out environment are exposed to complex mixtures that are not generally restricted to hydrocarbons alone. It is reasonable to expect that components of such complex mixtures may interact to produce additive effects that do not influence the toxicity of individual components, and synergistic or antagonistic effects. This investigation has shown the relative, potential of various accumulation and transmission pathway lead

Table II. Concentration and bioaccumulation factor of total petroleum hydrocarbon compound (Nonane) in six different fresh fish species from Qua Ibeo river of Eket Community

\begin{tabular}{llc}
\hline Samples & Nonane $(\mathrm{mg} / \mathrm{L})$ & BAF \\
\hline African Red snapper (Lutjanus agennes) & $3.9565 \pm 4.64648$ & 439,616275 \\
Barracuda Fish (Sphyraena barracuda) & $6.2555 \pm 0.48889$ & 695,067209 \\
Tilapia Fish (Oreochromis niloticus) & $6.0039 \pm 0.96487$ & 667,101072 \\
Croker Fish (Micropogonias undulates) & $9.3866 \pm 0.42208$ & 104,2956024 \\
Yellow Tail Fish (Seriola lalandi) & $8.7243 \pm 2.15546$ & 969,369061 \\
Cat Fish (Clarias gariepinus) & $4.1973 \pm 1.52959$ & 466,368366 \\
Water samples (Sample 1 to 12) & $9 \times 10^{-9}$ & \\
\hline
\end{tabular}

over the years, revealed that most fish species acquire higher concentration of TPH in dry season compared with wet season. This indicated an important fact that TPH concentration not only varies between the tissues of different fish species but varied in the same species, depending on the season. The increased hydrocarbon concentration in dry season may probably be due to the active intake during the cooler season and as a result, large amounts are stored. El-Deeb (1998) has reported that slackness in movement of fish in dry season, particularly demersal species, nearer the bottom provides favorable condition for bioaccumulation of petroleum hydrocarbons in tissues and changes taking place in the environmental conditions of the habitat (Shriadah, 1999 and 2001).

\section{Conclusion}

A susceptible fish will exhibit a different or enhanced response to petroleum hydrocarbons than some other fishes exposed to the same level of petroleum hydrocarbons in the environment. Reasons may include genetic makeup, age, health and nutritional status, and exposure to other toxic substances. These parameters may result in reduced detoxification or excretion of petroleum hydrocarbons as evidence in this research, or compromised function or organs affected by petroleum hydrocarbons. Individuals exposed to TPH in the ing health-impairing contaminants back to man via food chain.

\section{Acknowledgement}

We appreciate sincerely Mr. Paul Nwachukwu of international energy service limited laboratory, who perform the extraction of samples and GC-/FID operation, for his time and knowledge. Mr. Akaka Christopher, the Head, Department of Medical Laboratory Science, Emmanuel Hospital, Eket, who help with the ice pack and vessel that convey the samples to the science laboratory.

\section{References}

Agency for Toxic Substances and Disease Registry (2007ad), Biennial Report, U.S. Department of health and human services Division of Health Studies Surveillance and Registries Branch Atlanta, Georgia.

American Petroleum Institute (API) (2001), Risk-based Methodologies for Evaluating Petroleum Hydrocarbon Impacts at Oil and Natural Gas E\&P Sites, API Publication 4709. www.api.org accessed 20th May, 2015. 
Anderson JN, Neff JM, Cox BA, Tatan HE and Hightower GM (1994), Characteristics of dispersions and water soluble extracts of crude oils and their toxicity to estuarine crustaceans and fish, Marine Biology, 27: 75-88.

Barron MG, Carls MG. Short JW and Rice SD (2003), Photo enhanced toxicity of aqueous phase and chemically dispersed weathered Alaska North Slope Crude oil to pacific herring eggs and lavae, Environmental Toxicology in Chemistry, 22(3): 650-660.

Beeby A (1993), Measuring the effect of pollution. In: Applying Ecology. Chapman and Hall, London, New York, pp. 112-118.

Brown ED, Norcross BL and Short J W (1996), An introduction to studies on the effects of Exxenvaldez oil spill in early life history stages of Pacific herring, clupaepallasi, in Prince Williian Sound, Alaska, Canadian Journal Fish Aquatic Science, 53: 2337-2342.

Calfee RD, Little EE, Clevel L and Barron MG (1999), Photoenhanced toxicity of a weathered oil to Ceriodaphniadubia reproduction. Environmental Society for Pollution Resources, 6: 207-212.

Capone DG. and Bauer JE (1992), Environmental microbiology. Clarendon, Oxford.

Domask WG (1998), Introduction to petroleum hydrocarbons. Chemistry and composition in relation to petroleum derived fuels and solvents. Renal Effects of petroleum hydrocarbons, Advanced Nodes and Environmental Toxicity, 18:1-26.

El-Deeb KZ and El-Ebiary EH (1998), 'Total aromatic hydrocarbon content in the muscle and liver lipid extracts of two sea bream fishes from the Arabian Gulf, Journal of Science Research, 6: 139-151.

EPA, (2000). Deposition of Air Pollutants to the Great Waters: Third Report to Congress. EPA-453-R-00-005. U.S. Environmental Protection Agency, Office of Air Quality Planning and Standards, Research Triangle Park, NC.

Falk H.L, Kotin P and Thompson S (2004), Inhibition of carcinogenesis. Archives Environmetal Health. 29: 169179.
FAO (Food and Agriculture Organization) (2012). Aquatic Sciences and Fisheries Information System (ASFIS) species list. Retrieved from http://www.fao.org/fishery/collection/asfis/en accessed 14th June, 2015.

Hall AJ, Hugunin K, Deaville R, Law RJ, Allchin CR and Jepson PD (2006), The risk of infection from polychlorinated biphenyl exposure in the Harbor Porpoise (Phocoenaphocoena): A case-control approach. Environmental Health Perspectives, 114: 704-711.

Heintz RA, Short J W and Rice SD (1999), Sensitivity of fish embryos to weathered crude oil Part 11.Increased mortality of puck salmon (onchorpynchusgorbusca) embryo incubating downstream from weathered Exxen Valdez crude oil. Environmental Toxicology in Chemistry, 18: 494-503.

International Maritime Organisation (IMO) (2005). Manual on Oil Pollution, Section 5; Combating Oil Spills. $2^{\text {nd }}$ Ed., IMO, London. pp 234.

Kaladumo COK (1996), The implications of gas flaring in the Niger Delta Environment. Proceedings of the 8th Biennial International NNPC Seminar. In: The petroleum Industry and the Nigerian Environment, Portharcourt, Nigeria. Pp. 277-290.

Klerks PL, Nyman JA and Bhattacharyya S (2004), Relationship between hydrocarbon measurements and toxicity to a chironomid, a fish larva and daphinid for oils and oil spill chemical treatments in laboratory freshwater marsh microcosms, Environmental Pollution, 129: 345-353.

Mazhar FM, Ashry MA and Fathalla MM (1997), Effect of environmental pollution by crude oil onthe Nile fish Clarias lazera. 11- Histopathological features. Procreative. Zoological. Society, 14: 381-390.

Moles, A. and B.L. Norcoss, (1998). Effects of oil-laden sediments on growth and health of juvenile flatfishes, Can. J. Fish. Aquatic Science, 55: 605-610.

Muniz PE, Danulat B, Yannicelli J, Garcia-Alonson G Medina and Bicergo MC (2004), Assessment of contamination by heavy metals and petroleum hydrocarbons in sediment of Montevideo Harbour (Uruguay), Environment, 29: 1019-1028. 
Neff JM (1979). Bioaccumulation in Marine Organisms. Effects of Contaminants from Oil Well Produced Water. Elsevier Science Publishers, Amsterdam. pp452.

Okpashi VE, Wallace I, Akpo DM (2015), Crude Oil Contaminant and Bio-remediation using Brewery Mash and Earthworm (Nsukkadrilus mbae.) a Consortium to Cleaning-up and Restoring Soil Fertility Potentials, Journal of Petroleum and Environmental Biotechnology 6: 223 . doi:10.4172/21577463.1000223

Pelletier MC, Burgess RM, Ho KT, Kuhn A, Mckinney RA, Ryba SA (1997), Phototoxicity of individual polycyclic aromatic hydrocarbons and petroleum to marine invertebrate lavae and juveniles, Environmental Toxicology in Chemistry, 16: 2190-2199.

Perry JJ (1990), Oil in the biosphere. Introduction to Environmental Toxicology (F. E. Guthrie and J. J. Perry Edn) Elsevier, New York. Pp. 198-209.

Shriadah MA (2001), Petroleum Hydrocarbons Concentrations in Arabian Gulf Fish Tissues. Environmental Contamination and Toxicology Bulletin, 67: 560-567.

Shriadah MA (1999), Oil contamination along oil tanker routes off the United Arab Emirates', Environmental Contamination and Toxicology Bulletin. 63: 203-210.
Tiido T, Rignell-Hydbom A, Jönsson BAG, Giwercman YL, Pederson HS, Wojtyniak B, Ludwicki JK, Lesovoy V, Zvyezday, V., and 10 others., (2006). Impact of PCB and p,p-DDE contaminants on human sperm Y:X chromosome ratio: studies on three European populations and the Inuit population in Greenland. Environmental Health Perspective, 114: 718-724.

US Environmental Protection Agency (USEPA) (1986). Quality criteria for water. Office of water Regulation; Standard, Washington, D.C. EPA, 44(5): 86-101.

Weber P (2003), Abandoned Seas: Reversing the Decline of the Oceans. Worldwatch Paper 116. Worldwatch Institute, Washington, D.C.

Yasser AG and Naser MD (2011), Impact of pollutants on fish collected from different parts of Shatt Al-Arab River: a histopathological study. Environmental Monitoring Assessment. 181(14): 175-182.

Received: 09 December 2015; Revised: 17 January 2016; Accepted: 31 January 2016. 